\title{
PENGARUH PROMOTIONAL MIX TERHADAP KEPUTUSAN MAHASISWA MEMILIH UNIVERSITAS SEBELAS MARET SURAKARTA
}

\author{
FERNALDI ANGGADHA RATNO \\ Fakultas Ekonomi dan Bisnis Islam IAIN Salatiga
}

Tujuan penelitian ini adalah untuk: (1) Mengetahui faktor promotional mix yang terdiri dari periklanan, promosi penjualan, hubungan masyarakat, penjualan perseorangan, pemasaran langsung memiliki pengaruh secara parsial terhadap keputusan mahasiswa memilih Universitas Sebelas Maret. (2) Mengetahui faktor promotional mix yang terdiri dari periklanan, promosi penjualan, hubungan masyarakat, penjualan perseorangan, pemasaran langsung memiliki pengaruh secara simultan terhadap keputusan mahasiswa memilih Universitas Sebelas Maret Surakarta. Sampel diambil dengan teknik quota sampling, teknik proportionate stratified random sampling. Pada penelitian ini besarnya jumlah sampel ditentukan sebanyak 100 responden. Teknik pengumpulan data yang digunakan adalah teknik kuesioner dengan skala Likert. Teknik analisis data yang digunakan adalah teknik analisis regresi linier berganda. Berdasarkan hasil penelitian dapat disimpulkan bahwa : (1) Adanya pengaruh promotional mix terhadap keputusan mahasiswa memilih Universitas Sebelas Maret Surakarta angkatan 2012. Hal ini ditunjukkan dengan nilai probabilitas $0,000<0,05$. (2) Hasil perhitungan data untuk variabel periklanan memiliki tingkat signifikansi 0,032 , variabel promosi penjualan memiliki tingkat signifikansi 0,036 , variabel hubungan masyarakat memiliki tingkat signifikansi 0,043 , variabel penjualan perseorangan memiliki tingkat signifikansi 0,026 dan variabel pemasaran langsung memiliki tingkat signifikansi 0,009 maka dapat disimpulkan bahwa variabel periklanan, promosi penjualan, hubungan masyarakat, penjualan perseorangan, dan pemasaran langsung memilki pengaruh terhadap keputusan mahasiswa. (3) Berdasarkan hasil perhitungan data nilai Adjusted R Square sebesar 0,511 sehingga dapat diartikan bahwa 51,1\% keputusan mahasiswa memilih Universitas Sebelas Maret dipengaruhi oleh promotional mix yang terdiri dari periklanan, promosi penjualan, hubungan masyarakat, penjualan perseorangan, dan pemasaran langsung sedangkan sisanya dipengaruhi oleh faktor lain.

Keywords: Promotional Mix, Keputusan Mahasiswa 


\section{LATAR BELAKANG}

Di era globalisasi sekarang ini merupakan suatu tantangan tersendiri bagi perguruan tinggi dalam menyediakan pelayanan pendidikan kepada masyarakat. Perlu diketahui bahwa pendidikan merupakan faktor penting dalam menciptakan sumber daya manusia yang unggul dan kompeten. Dalam upaya menciptakan sumber daya yang kompeten dan unggul, perguruan tinggi memberikan pilihan program studi kepada mahasiswa atau calon mahasiswa untuk peningkatan khasanah ilmu pengetahuan.

Setiap Perguruan Tinggi Negeri, khususnya UNS menganggap bahwa promosi merupakan hal yang penting untuk dipahami oleh seluruh jajaran pengembang Universitas Sebelas Maret. Promosi dari produk pendidikan dijenjang pendidikan tinggi mengharuskan UNS untuk terus melakukan pengembangan di berbagai aspek bauran promosi yang dilakukan.

UNS berusaha menjaga kualitas jasa yang ditawarkan agar selalu berada diatas saingan dan lebih hebat dari yang dibayangkan oleh konsumen. Hasilnya, UNS mampu meraih jumlah mahasiswa yang cukup besar setiap tahun sesuai dengan Tabel 1.

Dapat dilihat di data tersebut, terjadi penurunan jumlah mahasiswa pada tahun 2009 dibandingkan dengan tahun 2008 sebanyak 3880 orang tetapi lonjakan penerimaan mahasiswa tahun 2010 menunjukkan prestasi penerimaan yang cukup tinggi yaitu sebanyak 8779 orang. Peningkatan peminat terjadi lagi pada tahun 2011 yaitu sebanyak 4858 orang namun, kenaikan tersebut tidak lebih baik dari kondisi yang terjadi pada tahun sebelumnya. Peningkatan yang cukup signifikan terjadi pada tahun 2012 dengan kenaikan jumlah peminat sebanyak 13618 orang.

Bauran promosi yang dilakukan UNS tidak terlepas dari pembahasan tentang periklanan, promosi penjualan, hubungan masyarakat, penjualan perseorangan, dan pemasaran langsung. Hal tersebut dapat terlihat di tabel bentuk bauran promosi yang dilakukan oleh UNS, sebagaimana yang terlihat pada Tabel 2.

Bentuk promosi yang dilakukan UNS, masih banyak kendala yang dihadapi dalam penyelenggaraannya. Misalnya saja dalam kegiatan kerjasama dengan seluruh media televisi swasta. Hal tersebut memang dilakukan, namun hanya sebatas hubungan kedekatan antara UNS dengan para jurnalis. UNS belum melakukan suatu kesepakatan tertulis dengan pihak media untuk membuat suatu acara promosi UNS yang diselenggarakan secara rutin. Apabila diadakan acara talkshow atau jumpa Pers, terkadang UNS tidak memiliki narasumber yang sesuai dengan topik yang dibicarakan. UNS pun hanya memiliki 2 (dua) orang karyawan untuk mengurus segala bidang promosi di UNS. Selanjutnya dalam melakukan promosi bidang advertising, UNS masih menggunakan jasa desainer dari pihak luar untuk mempersiapkan spanduk, baliho, brosur, dan lain-lain. Sehingga kegiatan ini memang menyedot anggaran yang cukup besar. Dan pembagian brosur di event car free day hanya dilakukan jika mendekati moment Seleksi Masuk Perguruan Tinggi Negeri saja.

Tujuan dari penelitian ini adalah untuk mengetahui variabel promotional mix yang terdiri

Tabel 1

Peminat UNS Program S-1 Tahun 2005 sampai dengan 2012

\begin{tabular}{cccc}
\hline No & Tahun SPMB & Pendaftar & Yang Melakukan Registrasi \\
\hline 1 & 2005 & 30.575 & 2672 \\
\hline 2 & 2006 & 33.407 & 3152 \\
\hline 3 & 2007 & 43.127 & 3284 \\
\hline 4 & 2008 & 64.418 & 4999 \\
\hline 5 & 2009 & 60.538 & 4394 \\
\hline 6 & 2010 & 69.317 & 4610 \\
\hline 7 & 2011 & 74.175 & 4485 \\
\hline 8 & 2012 & 88.333 & 5602 \\
\hline
\end{tabular}

Sumber: Bagian Pendidikan Universitas Sebelas Maret 
dari periklanan, promosi penjualan, hubungan masyarakat, penjualan perseorangan, dan pemasaran langsung memiliki pengaruh secara parsial terhadap keputusan mahasiswa memilih Universitas Sebelas Maret. Serta untuk mengetahui variabel promotional mix yang terdiri dari periklanan, promosi penjualan, hubungan masyarakat, penjualan perseorangan, dan pemasaran langsung memiliki pengaruh secara simultan terhadap keputusan mahasiswa memilih Universitas Sebelas Maret.

Penelitian ini terfokus pada konsep promotional mix yang terdiri dari 5 variabel yang mempengaruhi loyalitas mahasiswa angkatan 2011 Universitas Sebelas Maret kampus Kentingan Surakarta.

\section{TINJAUAN TEORITIS}

\section{Tinjauan Tentang Pemasaran}

Pengertian pemasaran sesuai dengan simpulan William J. Staton (2006) dalam (Harini, 2008) adalah: Suatu sistem keseluruhan dari kegiatankegiatan usaha yang ditujukan untuk merencanakan, menentukan harga, mempromosikan dan mendistribusikan barang-barang dan jasa yang dapat memuaskan kebutuhan baik kepada pembeli yang ada maupun kepada pembeli yang potensial.

Sedangkan menurut Kotler (2007) dalam (Harini, 2008) mendefinisikan marketing adalah: sebagai suatu proses sosial dan manajerial melalui proses tersebut individu dan kelompok memperoleh apa yang mereka butuhkan serta inginkan lewat penciptaan, dan pertukaran timbal balik produk-produk dan nilai dengan orang lain.

Pemasaran merupakan suatu proses yang meliputi analisis perencanaan dan pengendalian; pemasaran juga mencakup kegiatan dalam penetapan harga, promosi dan pendistribusian barang dan jasa untuk pertukaran

\section{Tinjauan Tentang Promotional Mix}

William J. Stanton yang dikutip Basu Swastha dan Irawan (2008:349) dalam bukunya Manajemen Pemasaran Modern mengemukakan bahwa, "Promotional Mix adalah kombinasi strategi yang paling baik dari variabel-variabel periklanan, personal selling, dan alat promosi yang lain, yang semuanya direncanakan untuk mencapai tujuan program penjualan".

Sedangkan Menurut Philip Kotler (2008: 116), mengemukakan bahwa "unsur bauran promosi (promotion mix), merupakan paduan spesifik iklan, promosi penjualan, hubungan masyarakat, penjualan personal, dan sarana pemasaran langsung yang digunakan perusahaan untuk mengkomunikasikan nilai pelanggan secara persuasif dan membangun hubungan pelanggan”.

Experiential marketing lebih dari sekedar memberikan informasi dan peluang kepada mahasiswa untuk memperoleh pengalaman atas keuntungan yang didapat dari jasa yang diberikan perguruan tinggi, tetapi juga membangkitkan emosi dan perasaan yang berdampak terhadap loyalitas mahasiswa itu sendiri.

\section{Periklanan}

Menurut Philip Kotler (2008), bahwa periklanan adalah segala bentuk presentasi non-pribadi dan promosi gagasan, barang, atau jasa oleh sponsor yang tertentu yang harus dibayar.

\section{Promosi Penjualan}

Menurut Kotler (2008) Promosi penjualan merupakan insentif jangka pendek untuk mendorong pembelian atau penjualan produk atau jasa. Contohnya, diskon, kupon, pajangan, dan demonstrasi. Berdasarkan definisi diatas, dapat disimpulkan bahwa Promosi Penjualan adalah kegiatan komunikasi yang bukan iklan, publisitas, atau penjualan pribadi. Tujuannya adalah menarik konsumen untuk membeli, yaitu dengan membuat pajangan di toko-toko, pameran, dan demonstrasi dengan menggunakan alat-alat penjualan seperti poster, selebaran, dan gambar tempel.

\section{Penjualan Perseorangan}

Basu Swastha dan Irawan (2008:350) mengemukakan definisi penjualan perseorangan dalam bukunya Manajemen Pemasaran Modern sebagai berikut, "Penjualan perseorangan adalah presentasi lisan dalam suatu percakapan dengan satu calon pembeli atau lebih yang ditujukan untuk menciptakan penjualan."

\section{Hubungan Masyarakat}

Sedangkan menurut Kotler (2008) mendefin- 
isikan hubungan masyarakat merupakan membangun hubungan baik dengan berbagai kalangan untuk mendapatkan publisitas yang diinginkan, membangun citra perusahaan yang baik, dan menangani atau meghadapi rumor, berita, dan kejadian tidak menyenangkan.

Dari definisi di atas dapat diambil suatu kesimpulan bahwa publisitas menguntungkan, contoh publisitas yang menguntungkan seseorang atau organisasi umumnya tidak memberikan atau tidak mengawasi medianya, sehingga dapat terjadi bahwa seseorang atau organisasi tidak mengetahui bahwa dirinya telah dipublikasikan.

\section{Pemasaran Langsung}

Kotler (2008:117) mendefinisikan pemasaran langsung sebagai hubungan langsung dengan konsumen individual yang ditargetkan secara cermat untuk memperoleh respons segera dan membangun hubungan pelanggan yang langgeng-penggunaan surat langsung, telepon, televisi respon langsung, e mail, internet, dan sarana lain untuk berkomunikasi secara langsung dengan konsumen tertentu. Bentuk pemasaran langsung meliputi Penjualan Personal, Pemasaran Pengeposan Langsung, Pemasaran Katalog, Pemasaran Telepon, Pemsaran Televisi Respon Langsung, Pemasaran Kios, Teknologi Baru Pemasaran Langsung Digital, dan Pemasaran Online.

\section{Tinjauan Tentang Keputusan Pembelian}

Menurut Kotler (2002) Keputusan pembelian adalah tindakan dari konsumen untuk mau membeli atau tidak terhadap produk. Dari berbagai faktor yang mempengaruhi konsumen dalam melakukan pembelian suatu produk atau jasa, biasanya konsumen selalu mempertimbangkan kualitas, harga dan produk sudah yang sudah dikenal oleh masyarakat Sebelum konsumen memutuskan untuk membeli, biasanya konsumen melalui beberapa tahap terlebih dahulu yaitu:

\section{Pengenalan Masalah}

Proses pembelian dimulai ketika pembeli mengenal suatu masalah atau kebutuhan. Pembeli menyadari suatu perbedaan antara keadaan sebenarnya dan keadaan yang diinginkan.

\section{Pencarian Informasi}

Tahap kedua dalam proses pembelian ini sangat berkaitan dengan informasi tentang sumbersumber dan menilainya, untuk memenuhi kebutuhan dan keinginan yang dirasakan. Melalui pengumpulan informasi, konsumen mengetahui produk-produk yang bersaing dan keistimewaan masing-masing produk.

\section{Penilaian Alternative}

Konsumen berusaha memuaskan suatu kebutuhan dan mencari manfaat tertentu dari suatu produk tersebut. Konsumen memandang setiap produk sebagai rangkaian atribut dengan kemampuan yang berbeda-beda dalam memberikan manfaat yang dicari dan memuaskan kebutuhan tersebut. Konsumen bersikap berbeda-beda dalam melihat atribut-atribut produk yang dianggap relevan dan menonjol. Mereka akan memberikan paling banyak perhatian pada atribut yang akan memberikan manfaat yang dicari.

\section{Keputusan untuk Membeli}

Keputusan untuk membeli di sini merupakan proses dalam pembelian yang nyata. Jadi, setelah tahap-tahap dimuka dilakukan maka konsumen harus mengambil keputusan apakah membeli atau tidak. Bila konsumen memutuskan untuk membeli, konsumen akan menjumpai serangkaian keputusan yang harus diambil menyangkut jenis produk, merek, penjual,kualitas, dan lain-lain.

\section{Perilaku Pasca Pembelian}

Setelah membeli satu produk, konsumen akan mengalami beberapa tingkat kepuasan atau ketidakpuasan. Konsumen juga akan melakukan beberapa kegiatan setelah membeli produk yang akan menarik bagi para pemasar. Tugas para pemasar belum selesai setelah produk dibeli oleh konsumen, namun akan terjadi hingga periode waktu pasca pembelian.

\section{Tinjauan Tentang Promotional Mix Terhadap Keputusan Pembelian}

Menurut Philip Kotler (2008: 116), mengemukakan bahwa unsur bauran promosi (promotion $m i x)$, merupakan paduan spesifik iklan, promosi penjualan, hubungan masyarakat, penjualan per- 
sonal, dan sarana pemasaran langsung yang digunakan perusahaan untuk mengkomunikasikan nilai pelanggan secara persuasif dan membangun hubungan pelanggan.

Menurut John A. Howard dan Jadgish N Sheth dalam (Ujang Sumarwan: 2002). Proses Keputusan konsumen dalam membeli atau mengkonsumsi produk dan jasa akan dipengaruhi oleh tiga faktor utama yaitu: (a) kegiatan pemasaran yang dilakukan oleh produsen dan lembaga lainnya, (b) faktor perbedaan individu konsumen, (c) faktor lingkungan konsumen.

Menurut Kotler (2002) Keputusan pembelian adalah tindakan dari konsumen untuk mau membeli atau tidak terhadap produk. Dari berbagai faktor yang mempengaruhi konsumen dalam melakukan pembelian suatu produk atau jasa, biasanya konsumen selalu mempertimbangkan kualitas, harga dan produk sudah yang sudah dikenal oleh masyarakat Sebelum konsumen memutuskan untuk membeli, biasanya konsumen melalui beberapa tahap terlebih dahulu yaitu, (1) pengenalan masalah, (2) pencarian informasi. (3) evaluasi alternatif, (4) keputusan membeli atau tidak, (5) perilaku pascapembelian.

Berdasarkan definisi tersebut, dapat dilihat dalam tahap keputusan pembelian poin ke-2 (dua), adalah tahap pencarian informasi. Pencarian dan penggalian informasi tentang kebutuhan konsumen dapat dilihat ketika konsumen mencapai tahap ke-2 dalam proses keputusan pembelian. Dalam penelitian ini, mahasiswa akan melihat informasi yang diberikan UNS mengenai Program yang dijalankan, Kegiatan Sponsorship, Pengembangan apa saja yang telah dilakukan, maupun sosialisasi tentang cara pendaftaran sistem online. Dan sesuai dengan yang dikemukakan oleh Basu Swastha (1999:246), iklan memiliki empat fungsi utama yaitu, memberikan informasi, membujuk atau mempengaruhi, menciptakan kesan, serta

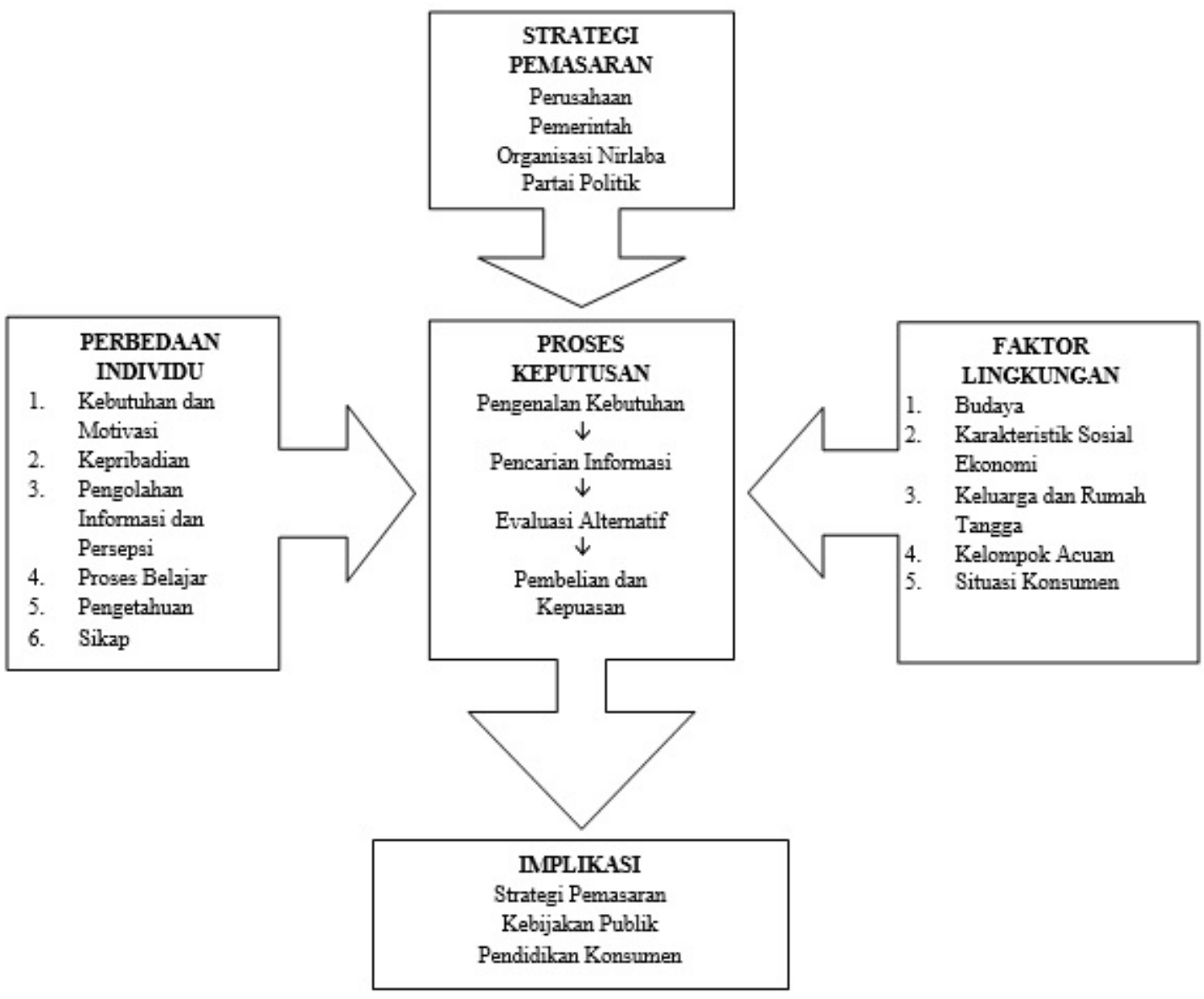

Gambar 1. Hal Yang Mempengaruhi Keputusan Pembelian Sumber: Ujang Sumarwan (2002) 
memuaskan keinginan, sebagai alat komunikasi. Semua iklan yang dikeluarkan oleh UNS mencakup berbagai informasi yang dibutuhkan oleh calon mahasiswa sebelum akhirnya mahasiswa tersebut sampai pada tahap inti keputusan pembelian, yaitu keputusan untuk membeli atau tidak.

\section{Hipotesis}

Hipotesis yang dirumuskan dalam penelitian ini adalah sebagai berikut:

H1 : Terdapat pengaruh yang signifikan secara parsial antara variabel bebas yaitu periklanan/ advertising (X1), terhadap Keputusan Pembel$\operatorname{ian}(\mathrm{Y})$

H2 : Terdapat pengaruh yang signifikan secara parsial antara variabel bebas yaitu penjuanlan promosi penjualan/sales promotion (X2), terhadap Keputusan Pembelian (Y).

H3 : Terdapat pengaruh yang signifikan secara parsial antara variabel bebas yaitu publisitas/ public relations $(\mathrm{X} 3)$, terhadap Keputusan Pembelian (Y).

H4 : Terdapat pengaruh yang signifikan secara parsial antara variabel bebas yaitu penjuanlan perseorangan/personal selling (X4), terhadap Keputusan Pembelian (Y).

H5 : Terdapat pengaruh yang signifikan secara parsial antara variabel bebas yaitu penjuanlan pemasaran langsung/direct marketing (X5), terhadap Keputusan Pembelian (Y).

H6 : Terdapat pengaruh yang signifikan secara simultan antara variabel bebas yaitu periklanan (advertising), penjualan perorangan (personal selling), hubungan masyarakat (public relations) promosi penjualan (sales promotion), Pemasaran Langsung (Direct Marketing) dengan variabel terikat yaitu keputusan pembelian.

\section{METODE PENELITIAN}

Metode yang digunakan dalam penelitian ini adalah penelitian diskriptif kuantitatif.

Populasi dalam penelitian ini adalah seluruh mahasiswa Universitas Sebelas Maret Kentingan Surakarta angkatan 2012 yang berjumlah 3838 orang.

Dalam penelitian ini penentuan besarnya

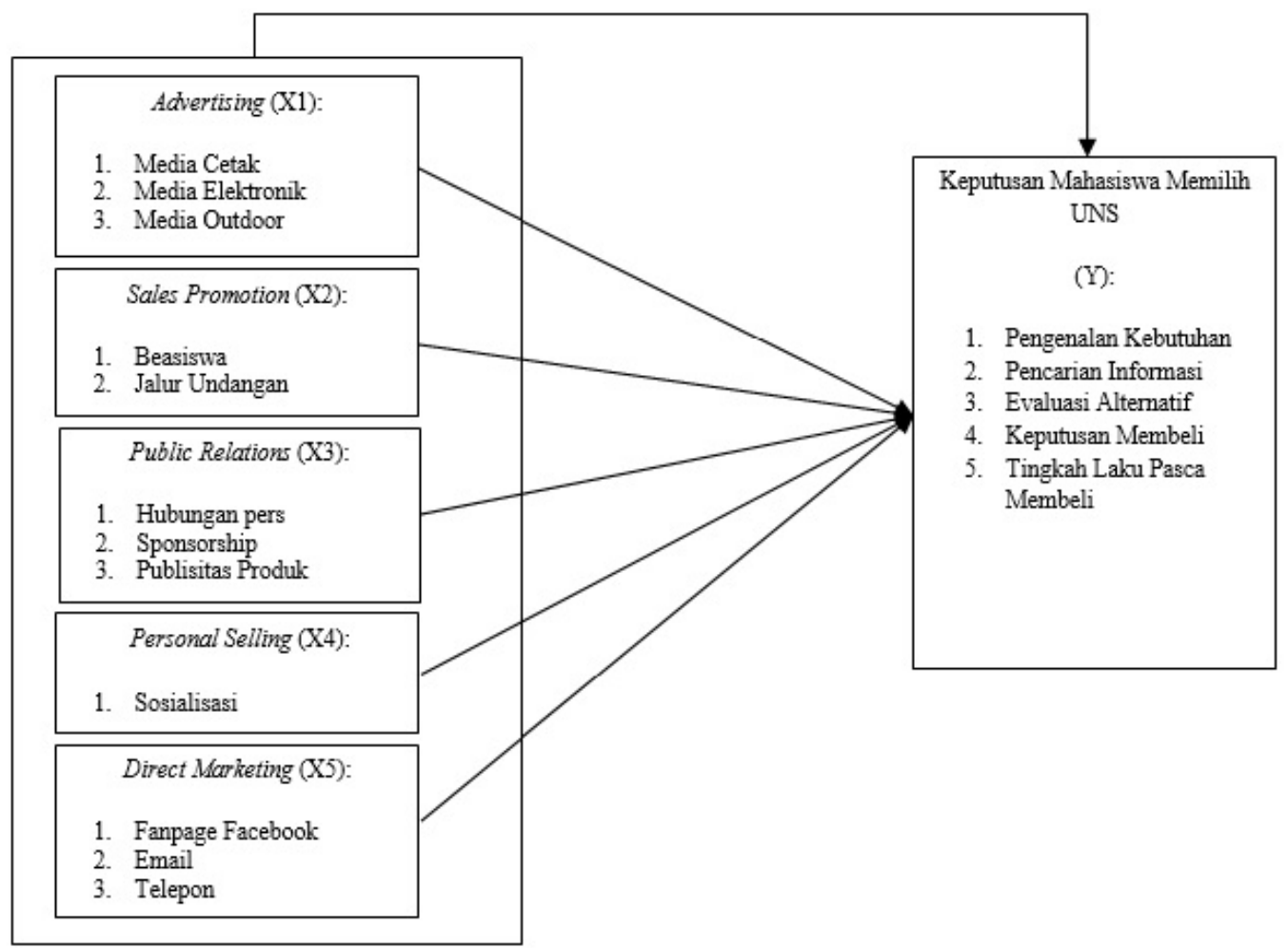

Gambar 2. Kerangka Berpikir

Sumber: Kotler \& Gary Armstrong (2008) 
sampel menggunakan rumus Slovin dalam (Husein Umar: 2008) sebagai berikut:

$$
n=\frac{N}{1+N(e)^{2}}
$$

Dimana:

$\mathrm{n}=$ jumlah sampel

$\mathrm{N}=$ jumlah populasi

e $=$ persen kelonggaran ketidaktelitian karena kesalahan pengambilan sampel, dalam penelitian ini nilai e sebesar 0,1 .

$$
\begin{gathered}
n=\frac{3838}{1+3838(0,1)^{2}} \\
n=100(\text { dibulatkan })
\end{gathered}
$$

Sampel yang digunakan dalam penelitian ini dibulatkan menjadi 100 mahasiswa.

\section{Teknik Pengambilan Sampel}

Penelitian ini menggunakan quota sampling dan proportionate stratified random sampling, quota sampling disini yaitu dengan menentukan jumlah sampling yang akan di gunakan sebagai responden penelitian. Penggunaan proportionte stratified random sampling dalam penelitian ini diperoleh jumlah sampel masing - masing fakultas untuk populasi mahasiswa Universitas Sebelas Maret Surakarta. Setelah didapat sampel yang proporsional selanjutnya sampel diacak dengan cara undian untuk menentukan mahasiswa mana dari masing-masing fakultas yang akan dijadikan sebagai responden dalam penelitian ini.

\section{Analisis Data dan Uji Hipotesis \\ Analisis Regresi}

Analisis regresi yang digunakan dalam peneli- tian ini adalah analisis regresi berganda dengan persamaan sebagai berikut:

$$
\boldsymbol{Y}=\boldsymbol{a}+b_{1} X_{1}+b_{2} X_{2}+b_{3} X_{3}+b_{4} X_{4}+b_{5} X_{5}
$$

Dimana:

$\mathrm{Y}=$ Keputusan Mahasiswa

$\mathrm{X}_{1}=$ Periklanan

$\mathrm{X}_{2}=$ Promosi Penjualan

$\mathrm{X}_{3}=$ Hubungan Masyarakat

$\mathrm{X}_{4}=$ Penjualan Perseorangan

$\mathrm{X}_{5}=$ Pemasaran Langsung

Pengukuran.

a = Bilangan konstanta

$\mathrm{b}=$ Koefisien regresi (nilai peningkatan ataupun penurunan).

\section{Uji F}

Uji $F$ digunakan untuk mengetahui variabel bebas secara bersama-sama mempunyai berpengaruh secara signifikan terhadap variabel terikat. Adapun langkah-langkah dari uji $\mathrm{F}$ adalah sebagai berikut :

\section{Hipotesis}

$$
\text { Ho : } b_{1}=b_{2}=b_{3}=b_{4}=b_{5}=0
$$

Berarti tidak ada pengaruh yang signifikan secara bersama-sama variabel independen (promotional mix) terhadap variabel dependen (keputusan mahasiswa).

$$
\text { Ha }: b_{1} \neq b_{2} \neq b_{3} \neq b_{4} \neq b_{5} \neq 0
$$

Berarti ada pengaruh yang signifikan secara bersama-sama variabel independen (promotional mix) terhadap variabel dependen (keputusan mahasiswa).

2. Tingkat signifikasi $(\alpha)=5 \%$

Tabel 2

Perhitungan Proporsional Sampling

\begin{tabular}{clccc}
\hline No & Fakultas & Tahun Akademik & Populasi & Sampel \\
\hline 1 & FKIP & 2012 & 1988 & $(1988 \div 3838) \times 100=52$ \\
\hline 2 & Pertanian & 2012 & 613 & $(613 \div 3838) \times 100=16$ \\
\hline 3 & FSSR & 2012 & 433 & $(433 \div 3838) \times 100=11$ \\
\hline 4 & Teknik & 2012 & 417 & $(417 \div 3838) \times 100=11$ \\
\hline 5 & Hukum & 2012 & 387 & $(387 \div 3838) \times 100=10$ \\
\hline & Jumlah & & 3838 & 100 \\
\hline
\end{tabular}


3. Rumus uji F

$$
F=\frac{R 2 /(k-1)}{(1-R 2) /(n-k)}
$$

Dimana:

$\mathrm{R}^{2}=$ Koefisien determinasi

$\mathrm{n}=$ Jumlah observasi

$\mathrm{k}=$ Jumlah variabel

4. Kriteria pengujian

Ho diterima dan Ha ditolak apabila $\mathrm{F}_{\text {hitung }}<\mathrm{F}_{\text {tabel }}$ atau probabilitas nilai $\mathrm{F}$ atau signifikan $>0,05$.

Ho ditolak dan Ha diterima apabila $\mathrm{F}_{\text {hitung }}>\mathrm{F}_{\text {ta- }}$ bel atau probabilitas nilai $\mathrm{F}$ atau signifikansi $<$ 0,05 .

Uji F dalam penelitian ini menggunakan software SPSS 17, yaitu dengan melihat tabel ANOVA dalam kolom sig, jika probabilitas $<0,05$, maka dapat dikatakan terdapat pengaruh yang signifikan secara bersama-sama variabel bebas (promotional mix) terhadap variabel terikat (keputusan mahasiswa) dan model regresi bisa dipakai untuk memprediksi variabel terikat.

\section{Uji t}

Uji t digunakan untuk menguji secara parsial masing-masing variabel. Adapun langkah-langkah dari uji $t$ adalah sebagai berikut:

1. Hipotesis

Ho : $b_{1}=b_{2}=b_{3}=b_{4}=b_{5}=0$

Berarti tidak ada pengaruh yang signifikan secara parsial variabel independen (promotional mix) terhadap variabel dependen (keputusan mahasiswa).

Ha : $b_{1} \neq b_{2} \neq b_{3} \neq b_{4} \neq b_{5} \neq 0$

Berarti ada pengaruh yang signifikan secara parsial variabel independen (promotional mix) terhadap variabel dependen (keputusan mahasiswa).

2. Tingkat signifikasi $(\alpha)=5 \%$

3. Rumus uji $\mathrm{t}$

$$
t=\frac{b i}{\sigma b i}
$$

Dimana:

$b i=$ Koefisien regresi

$\sigma b i=$ Standar error koefisien regresi

4. Kriteria pengujian

Ho diterima dan Ha ditolak apabila $\mathrm{t}_{\text {hitung }}<\mathrm{t}$ tabel atau probabilitas nilai $\mathrm{t}$ atau signifikan $>0,05$.

Ho ditolak dan Ha diterima apabila $\mathrm{t}_{\text {hitung }}>\mathrm{t}_{\text {tabel }}$ atau probabilitas nilai $\mathrm{t}$ atau signifikansi $<$ 0,05 .

Uji t dalam penelitian ini menggunakan software SPSS 17, yaitu dengan melihat tabel coefficients pada kolom sig. Jika probabilitas nilai t atau signifikansi $<0,05$, maka dapat dikatakan bahwa terdapat pengaruh secara parsial antara variabel bebas (promotional mix) terhadap variabel terikat (keputusan mahasiswa).

\section{Koefisien Determinasi (Adjusted R Square)}

Hasil perhitungan Adjusted $R^{2}$ dapat dilihat pada output Model Summary. Pada kolom Adjusted $R^{2}$ dapat diketahui berapa prosentase yang dapat dijelaskan oleh variabel-variabel bebas terhadap variabel terikat. Dan sisanya dipengaruhi atau dijelaskan oleh variabel-variabel lain yang tidak dimasukkan dalam model penelitian ini.

\section{HASIL DAN PEMBAHASAN}

\section{Analisis Regresi Ganda}

Berdasarkan Tabel Coefficients, maka persamaan regresi yang diperoleh adalah sebagai berikut:

$$
\begin{gathered}
Y=-1,232+0,171 X_{1}+0,344 X_{2}+0,313 X_{3}+ \\
0,341 X_{4}+0,329 X_{5}
\end{gathered}
$$

Dimana:

$\mathrm{Y}=$ Keputusan Mahasiswa

$\mathrm{X}_{1}=$ Periklanan

$\mathrm{X}_{2}=$ Promosi Penjualan

$\mathrm{X}_{3}=$ Hubungan Masyarakat

$\mathrm{X}_{4}=$ Penjualan Perseorangan

$\mathrm{X}_{5}=$ Pemasaran Langsung

Berdasarkan persamaan regresi tersebut dapat diinterpretasikan sebagai berikut:

a. Konstanta/intersep sebesar 17.557 secara matematis menyatakan bahwa jika nilai variabel bebas $\mathrm{X}_{1}, \mathrm{X}_{2}$ dan $\mathrm{X}_{3}$ sama dengan nol maka nilai $Y$ adalah 17.557.

b. Koefisien regresi variabel periklanan $\left(\mathrm{X}_{1}\right)$ sebesar 0,209 artinya sense mempunyai pen- 
Tabel 3

Koefisien Regresi

Coefficients $^{a}$

\begin{tabular}{|c|c|c|c|c|c|c|}
\hline \multirow{2}{*}{ Model } & \multirow[b]{2}{*}{ B } & \multicolumn{2}{|c|}{$\begin{array}{l}\text { Unstandardized Coeffi- } \\
\text { cients }\end{array}$} & \multirow[t]{2}{*}{$\begin{array}{l}\text { Standardized } \\
\text { Coefficients }\end{array}$} & \multirow[b]{2}{*}{$\mathbf{T}$} & \multirow[b]{2}{*}{ Sig. } \\
\hline & & Std. Error & Beta & & & \\
\hline \multirow[t]{6}{*}{1} & (Constant) & 17.557 & 2.904 & & 6.046 & 0,000 \\
\hline & Periklanan & 0,209 & 0,096 & 0,210 & 2.170 & 0,032 \\
\hline & Promosi Penjualan & 0,289 & 0,136 & 0,161 & 2.124 & 0,036 \\
\hline & Hubungan Masyarakat & 0,339 & 0,166 & 0,184 & 2.047 & 0,043 \\
\hline & Penjualan Perseorangan & 0,253 & 0,112 & 0,212 & 2.265 & 0,026 \\
\hline & Pemasaran Langsung & 0,482 & 0,181 & 0,226 & 2.661 & 0,009 \\
\hline
\end{tabular}

a. Dependent Variable: Keputusan Mahasiswa

Sumber: Data primer yang diolah 2013

Tabel 4

ANOVA $^{b}$

\begin{tabular}{llrrrrr}
\hline \multicolumn{1}{l}{ Model } & Sum of Squares & Df & Mean Square & F & Sig. \\
\hline \multirow{2}{*}{1} & Regression & 863,779 & 5 & 172,756 & 21,712 & $0,000^{\mathrm{a}}$ \\
\cline { 2 - 7 } & Residual & 747,931 & 94 & 7,957 & & \\
\cline { 2 - 7 } & Total & 1611,710 & 99 & & & \\
\hline
\end{tabular}

a. Predictors: (Constant), Periklanan, Promosi Penjualan, Hubungan Masyarakat, Penjualan Perseorangan, Pemasaran Langsung

b. Dependent Variable: Keputusan Mahasiswa

Sumber: Data primer yang diolah, 2013)

garuh yang positif terhadap variabel keputusan mahasiswa. Sedangkan koefisien 0,209 berarti bahwa peningkatan satu unit variable periklanan dengan asumsi variabel bebas lain konstan akan menyebabkan kenaikan loyalitas mahasiswa sebesar 0,209.

c. Koefisien regresi variable promosi penjualan $\left(\mathrm{X}_{2}\right)$ sebesar 0,289 artinya promosi penjualan mempunyai pengaruh yang positif terhadap variabel loyalitas mahasiswa. Sedangkan koefisien 0,289 berarti bahwa peningkatan satu unit variabel promosi penjualan dengan asumsi variabel bebas lain konstan akan menyebabkan kenaikan loyalitas mahasiswa sebesar 0,289 .

d. Koefisien regresi variabel hubungan masyarakat $\left(\mathrm{X}_{3}\right)$ sebesar 0,339 artinya hubungan masyarakat mempunyai pengaruh yang positif terhadap variabel loyalitas mahasiswa. Sedangkan koefisien 0,339 berarti bahwa peningkatan satu unit variabel hubungan masyarakat dengan asumsi variabel bebas lain konstan akan menyebabkan kenaikan loyalitas mahasiswa sebesar 0,339.

e. Koefisien regresi variabel penjualan perse- orangan $\left(\mathrm{X}_{4}\right)$ sebesar 0,253 artinya penjualan perseorangan mempunyai pengaruh yang positif terhadap loyalitas mahasiswa. Sedangkan koefisien 0,253 berarti bahwa peningkatan satu unit variabel penjualan perseorangan dengan asumsi variabel bebas lain konstan akan menyebabkan kenaikan loyalitas mahasiswa sebesar 0,253.

f. Koefisien regresi variabel pemasaran langsung $\left(\mathrm{X}_{5}\right)$ sebesar 0,482 artinya pemasaran langsung mempunyai pengaruh yang positif terhadap variabel loyalitas mahasiswa. Sedangkan koefisien 0,482 berarti bahwa peningkatan satu unit variabel pemasaran langsung dengan asumsi variabel bebas lain konstan akan menyebabkan kenaikan loyalitas mahasiswa sebesar 0,482 unit.

\section{Uji F}

Berdasarkan Tabel ANOVA di atas dapat dilihat bahwa nilai probabilitas dalam kolom Sig. adalah 0,000 , dimana nilai ini lebih kecil dari 0,05 $(0,000<0,05)$. Oleh karena itu, dapat disimpulkan bahwa Ho ditolak dan $\mathrm{H}_{\mathrm{a}}$ diterima yang artinya terdapat pengaruh yang signifikan secara bersa- 


\section{KESIMPULAN}

Berdasarkan hasil penelitian, maka dapat diambil kesimpulan sebagai berikut:

Berdasarkan hasil analisis statistik untuk menguji hipotesis yang telah dilakukan dengan analisis regresi linier berganda dan pembahasan analisis data, maka dapat diambil kesimpulan bahwa hipotesis pertama dan kedua penelitian yang menyatakan bahwa 5 variabel promotional mix yang terdiri dari advertising (X1), sales promotion (X2), public relation (X3), personal selling (X4) dan direct marketing (X5) memiliki pengaruh secara simultan dan parsial terhadap keputusan mahasiswa memilih Universitas Sebelas Maret.

Variabel experiential marketing yang terdiri dari advertising (X1), sales promotion (X2), public relation $(\mathrm{X} 3)$, personal selling $(\mathrm{X} 4)$ dan direct marketing (X5) memiliki pengaruh positif terhadap keputusan mahasiswa. Berdasarkan analisis yang telah dilakukan, dapat diketahui bahwa variabel direct marketing memiliki nilai koefisien terbesar dibanding dengan variabel bebas lainnya, sehingga variabel direct marketing yang terdiri dari tiga indikator yaitu Fanpage Facebook, Email, Telepon memberikan pengaruh paling besar terhadap keputusan mahasiswa. Untuk variabel yang memberikan pengaruh paling lemah terhadap loyalitas mahasiswa yaitu variabel public relation.

\section{Implikasi}

Implikasi yang dapat dikemukakan dalam penelitian ini adalah sebagai berikut:

1. Hasil penelitian menunjukkan bahwa Periklanan berpengaruh terhadap terhadap keputusan mahasiswa memilih UNS Surakarta. Periklanan yang berupa iklan yang ditampilkan melalui media cetak, media elektronik, dan media outdoor yang dilakukan oleh UNS akan berpengaruh dalam peningkatan keputusan mahasiswa. Oleh karena itu, pihak UNS perlu memperbaiki dan meningkatkan media iklan melalui media cetak, elektronik, dan media outdoor karena akan berdampak positif terhadap keputusan mahasiswa memilih UNS Surakarta.

2. Hasil penelitian menunjukkan bahwa vari- abel promosi penjualan berpengaruh terhadap terhadap keputusan mahasiswa memilih UNS Surakarta. Variabel promosi penjualan yang berupa menyediakan SNMPTN Jalur Undangan dan berbagai program beasiswa akan berpengaruh dalam peningkatan Keputusan Mahasiswa. Oleh karena itu, pihak UNS seharusnya dapat meningkatkan dan memperbanyak kuota untuk SNMPTN Jalur Undangan dan memperbanyak kerjasama dengan berbagai instansi untuk memberikan beasiswa karena akan berdampak positif terhadap keputusan mahasiswa memilih UNS Surakarta.

3. Hasil penelitian menunjukkan bahwa Hubungan Masyarakat berpengaruh terhadap terhadap keputusan mahasiswa memilih UNS Surakarta. Hubungan Masyarakat yang berupa hubungan pers, sponsorship, dan publisitas produk yang dilakukan oleh UNS akan berpengaruh dalam peningkatan keputusan mahasiswa. Oleh karena itu, pihak UNS perlu memperbanyak penyebaran informasi penting di berbagai media, meningkatkan loyalitas dalam pendanaan berbagai kegiatan di masyarakat, dan meningkatkan intensitas publisitas produk karena akan berdampak positif terhadap keputusan mahasiswa memilih UNS Surakarta.

4. Hasil penelitian menunjukkan bahwa variabel Penjualan Perseorangan berpengaruh terhadap terhadap keputusan mahasiswa memilih UNS Surakarta. Penjualan Perseorangan yang berupa sosialisasi yang dilakukan di berbagai sekolah yang dilakukan oleh UNS akan berpengaruh dalam peningkatan keputusan mahasiswa. Oleh karena itu, pihak UNS perlu meningkatkan intensitas kegiatan sosialisasi di tiap sekolah dan memperluas daerah sosialisasi karena akan berdampak positif terhadap keputusan mahasiswa di UNS Surakarta.

5. Hasil penelitian menunjukkan bahwa variabel Pemasaran langsung berpengaruh terhadap keputusan mahasiswa memilih UNS Surakarta. Variabel Pemasaran langsung yang berupa pemasaran melalui internet, surat elektronik, dan telepon yang diterapkan oleh UNS akan berpengaruh dalam peningkatan keputusan mahasiswa. Oleh karena itu, pihak UNS perlu menambah akun di jejaring sosial, surat ele- 
ktronik, dan menyediakan operator telepon yang kompeten dan cakap dalam berkomunikasi karena akan berdampak positif terhadap keputusan mahasiswa memilih UNS.

\section{SARAN}

1. UNS perlu mengembangkan media yang digunakan dalam periklanan. Contohnya, pembagian brosur hendaknya dilakukan tidak hanya mendekati SNMPTN saja, tetapi dilakukan secara kontinyu tiap bulan untuk menginformasikan mengenai UNS, selain itu acara UNS Menyapa juga disiarkan di stasiun televisi berskala nasional seperti RCTI, MetroTV, Global Tv, SCTV agar diketahui oleh masyarakat luas, untuk pemasangan spanduk hendaknya tidak hanya dilakukan di dalam kota Surakarta saja, tetapi ke Kota lain bahkan lintas Propinsi.

2. UNS perlu mengembangkan promosi penjualan. Contohnya, UNS perlu menambah kuota untuk SNMPTN Jalur Undangan dan meningkatkan kerjasama dengan berbagai instansi swasta skala nasional seperti Indofood, Gudang Garam, Putera Sampoerna Foundation.

3. UNS perlu mengembangkan kegiatan hubungan masyarakat. Contohnya, UNS perlu memperbanyak informasi yang disebarkan di berbagai koran, tidak hanya di Jawa Pos dan Solo Pos, tetapi perlu disampaikan di Kompas, Suara Merdeka, Media Indonesia dan UNS perlu meningkatkan pendanaan di berbagai kegiatan di masyarakat serta Publikasi produk yang dilakukan oleh UNS tidak hanya melalui media cetak saja tetapi juga dilakukan di media elektronik, contohnya pembukaan prodi baru hendaknya ditampilkan di TATV.

4. UNS perlu mengembangkan kegiatan penjualan perseorangan yang dilakukan oleh UNS Kegiatan sosialisasi di luar Jawa hendaknya ditingkatkan, tidak hanya di Bontang saja tetapi juga ke Kota besar lain di luar Jawa seperti Padang, Makassar, Medan, bahkan Jayapura.

5. UNS perlu mengembangkan kegiatan pemasaran langsung yang dilakukan oleh UNS. UNS perlu menambah akun di jejaring sosial twitter, foursquare, path yang sedang populer saat ini agar lebih dekat dengan mahasiswa sehingga semua saran dan keluhan bisa ditampung, selain itu UNS juga perlu menambah operator telepon untuk memudahkan berkomunikasi dengan mahasiswa, sehingga bila telepon sedang online masih bisa dihubungi karena ada operator lain. 


\section{REFERENSI}

Alfarisy Totalia, Salman \& Hindrayani, Aniek. (2010). Teknik Pengolahan Data. Surakarta: UNS Press

Alma, Buchari. (2009). Manajemen Pemasaran dan Pemasaran Jasa. Bandung: Alfabeta.

Arikunto, Suharsimi (2006). Prosedur Penelitian: Suatu Pendekatan Praktek. Jakarta: Rineka Cipta.

Armstrong, Gary \& Philip Kotler. (2002). Dasar-Dasar Pemasaran. Alih Bahasa Alexander Sindoro dan Benyamin Molan. Jilid I, Erlangga, Jakarta.

Duwi Priyatno. (2008). Mandiri Belajar SPSS (Statistic Product and Servise Solution). Yogyakarta: Mediacom.

Harini. (2008). Dasar-Dasar Pemasaran. Surakarta: UNS Press

Hasan, M Iqbal. (2002). Pokok-Pokok Materi Statistik2 Edisi Kedua. Jakarta: Bumi Aksara.

Kotler Philip, (1996). Manajemen Pemasaran (Analisis, Perencanaan, dan Pengendalian), Terjemahan Drs. Jaka Wasana MSM, Institut dan Pembinaan Manajemen, Jilid I, Edisi Kelima, Erlangga, Cetakan Ketujuh, Jakarta.

(1997). Manajemen Pemasaran. Prenhallindo. Jakarta.

(2001). Manajemen Pemasaran di Indonesia, Terjemahan Susanto. Salemba Empat: Jakarta.

(2004). Manajemen Pemasaran, Edisi Millenium, Prenhallindo, Jakarta.

(2008). Prinsip-Prinsip Pemasaran, Edisi Keduabelas, Jilid II, Erlangga, Jakarta,

Lestari, Berta \& Noor, Aris Setia. (2011). Jurnal Ilmu-Ilmu Sosial: Analisis Keputusan Bauran Promosi Yang Mempengaruhi Proses Pembelian Konsumen Pada Perusahaan Batik Irmasasirangan Di Kota Banjarmasin

Lupiyoadi \& Hamdani, (2009). A. Manajemen Pemasaran Jasa, Edisi Kedua, Salemba Empat, Jakarta.

Mowen \& Minor, (2002). Perilaku Konsumen. Alih Bahasa Lina. Salim, Erlangga, Jakarta.

Narbuko, Cholid \& Achmadi, Abu. (2007). Metodelogi Penelitian. Bumi Aksara, Jakarta.

Priyatno, Dwi. (2008). Mandiri Belajar SPSS. Mediakom, Yogyakarta.

Singgih Santoso. (2001). Buku Latihan SPSS Statistik Parametik. Jakarta: T.Elex Media Komputindo.

Sugiyono. (2005). Statistik untuk Penelitian. Bandung: Alfabeta

(2009). Metode Penelitian Kuantitatif dan Kualitatif. Bandung: Alfabeta 
(2010). Metode Penelitian Kuantitatif Kualitatif dan R\&D. Bandung: Alfabeta

Suharsimi Arikunto. (2006). Prosedur Penelitian: Suatu Pendekatan Praktek. Jakarta: Rineka Cipta.

Sumarwan, Ujang. (2004). Perilaku Konsumen "Teori dan Penerapannya dalam Pemasaran”, Bogor: Ghalia Indonesia.

Swastha, Basu. (1999). Azas-Azas Marketing. Jogjakarta: Liberty

Swastha, Basu \& Irawan. (2008). Manajemen Pemasaran Modern. Jogjakarta: Liberty

Swastha, Basu \& Hani Handoko. (1997). Manajemen Pemasaran Analisa Perilaku Konsumen. Gramedia Pustaka Utama.

(2000). Manajemen Pemasaran (Analisa Perilaku Konsumen). BPFE, Yogyakarta.

Sutisna. (2002). Perilaku Konsumen \& Komunikasi Pemasaran. Remaja Rosdakarya, Bandung.

Tjiptono, Fandy. (1997). Strategi Pemasaran, Edisi Kedua, ANDI, Yogyakarta.

. (2002). Strategi Pemasaran. Yogyakarta: Andi

Umar, Husein (2003). Metode Riset Perilaku Konsumen Jasa. Jakarta: Ghalia Indonesia 